\title{
Selenium-containing heterocycles from isoselenocyanates: Base-catalyzed reaction of malononitrile with phenyl isoselenocyanate and bromoacetonitrile or alpha-halogenated ketones
}

\author{
Sommen, G L ; Linden, Anthony ; Heimgartner, H
}

\begin{abstract}
The reaction of phenyl isoselenocyanate (1a) with malononitrile (= propanedinitrile) in DMF in the presence of Et3N leads to the intermediate ketene N,Se-hemiacetal 6a, which can be trapped with bromoacetonitrile or a-halogenated ketones 12a and 12b (Scheme 3). The products are [(alkylseleno)(phenylamino)methylene]malononitriles 10 and 13, which are obtained in good yield. In the case of the (2-oxoalkyl)seleno derivatives 13 , they are in equilibrium with the cyclic hemiacetals 14 . Chemical and spectroscopic evidence for the structures of the new compounds are described. The structure of 14a was established by X-ray crystallography.
\end{abstract}

DOI: https://doi.org/10.1002/hlca.200790194

Posted at the Zurich Open Repository and Archive, University of Zurich

ZORA URL: https://doi.org/10.5167/uzh-50027

Journal Article

Accepted Version

Originally published at:

Sommen, G L; Linden, Anthony; Heimgartner, H (2007). Selenium-containing heterocycles from isoselenocyanates: Base-catalyzed reaction of malononitrile with phenyl isoselenocyanate and bromoacetonitrile or alpha-halogenated ketones. Helvetica Chimica Acta, 90(10):1849-1855.

DOI: https://doi.org/10.1002/hlca.200790194 


\section{Selenium-Containing Heterocycles from Isoselenocyanates: Base-Catalyzed Reaction of Malononitrile with Phenyl Isoselenocyanate and Bromoacetonitrile or $\alpha$-Halogenated Ketones}

by Geoffroy L. Sommen ${ }^{1}$ ), Anthony Linden, and Heinz Heimgartner*

Organisch Chemisches Institut der Universität Zürich, Winterthurerstrasse 190, CH 8057 Zürich

(phone: +41446354282; fax: +41446356836; e mail: heimgart@oci.uzh.ch)

The reaction of phenyl isoselenocyanate (1a) with malononitrile ( propanedinitrile) in DMF in the presence of $\mathrm{Et}_{3} \mathrm{~N}$ leads to the intermediate ketene $\mathrm{N}, \mathrm{Se}$ hemiacetal $\mathbf{6 a}$, which can be trapped with bromoacetonitrile or $\alpha$ halogenated ketones 12a and 12b (Scheme 3). The products are [(alkylseleno) (phenylamino)methylene]malononitriles $\mathbf{1 0}$ and $\mathbf{1 3}$, which are obtained in good yield. In the case of the ( 2 oxoalkyl)seleno derivatives $\mathbf{1 3}$, they are in equilibrium with the cyclic hemiacetals $\mathbf{1 4}$. Chemical and spectroscopic evidence for the structures of the new compounds are described. The structure of 14a was established by X ray crystallography.

1. Introduction. - In the last few years, it has been shown that isoselenocyanates $\mathbf{1}$ are versatile building blocks for the synthesis of selenium-containing heterocycles [14] and heterocyclic selones (see [5-6] and refs. cit. therein). For example, the reaction of $\mathbf{1}$ with nucleophiles of type $\mathbf{2}$, which also bear an electrophilic group, in the presence of a base gave either Se-containing heterocycles 4 with an imino group or $\mathrm{N}$-containing heterocycles 5 with a selenoxo group (Scheme 1). A likely intermediate is $\mathbf{3}$, which undergoes a 5- or 6-exo-tet cyclization [7] via the Se- and $\mathrm{N}$-atom, respectively.

Scheme 1

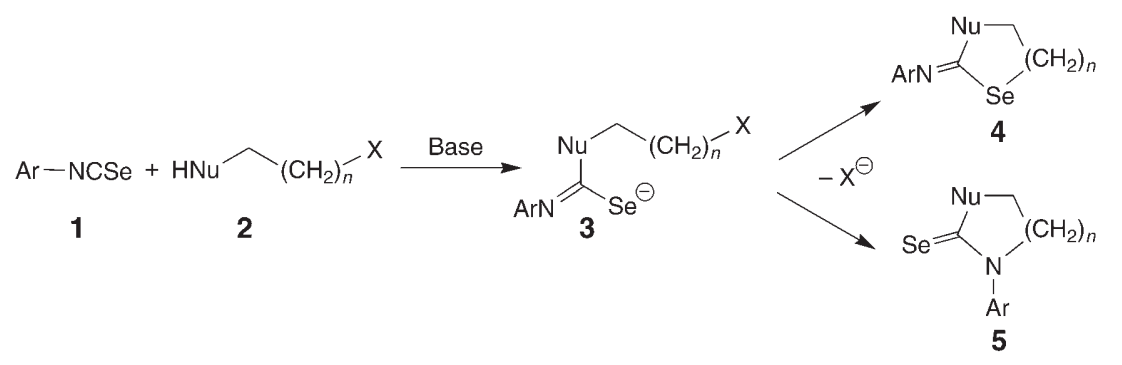

Recently, we have shown that 'three-component reactions' of $\mathbf{1}$, cyanomethylene derivatives, and bis-electrophiles in the presence of a base yield 2-methylene-1,3-

1) Postdoctoral stay at the University of Zürich (08.2004 08.2005). Present address: Lonza Braine SA, Chaussée de Tubize 297, Bâtiment B8P2, 1420 Braine l'Alleud, Belgium; e mail: geoffroy.som men@lonza.com. 
selenazolidine [8] and analogous 1,3-selenazinane (=tetrahydro-1H-1,3-selenazine) derivatives [9] (Scheme 2). For example, the reactions with 1,2-dibromoethane or 2bromoacetyl bromide yield 7, and the analogous reactions with 1,3-dibromopropane, 1,3-dichloroacetone, and 3-chloropropanoyl chloride, respectively, give the six-membered products $\mathbf{8}^{2}$ ) or $\mathbf{9}$. The crucial intermediate of these reactions is the $\mathrm{N}, \mathrm{Se}-$ hemiacetal $\mathbf{6}$, which in all cases reacted with the bis-electrophilic reagent by double nucleophilic substitution.

Scheme 2

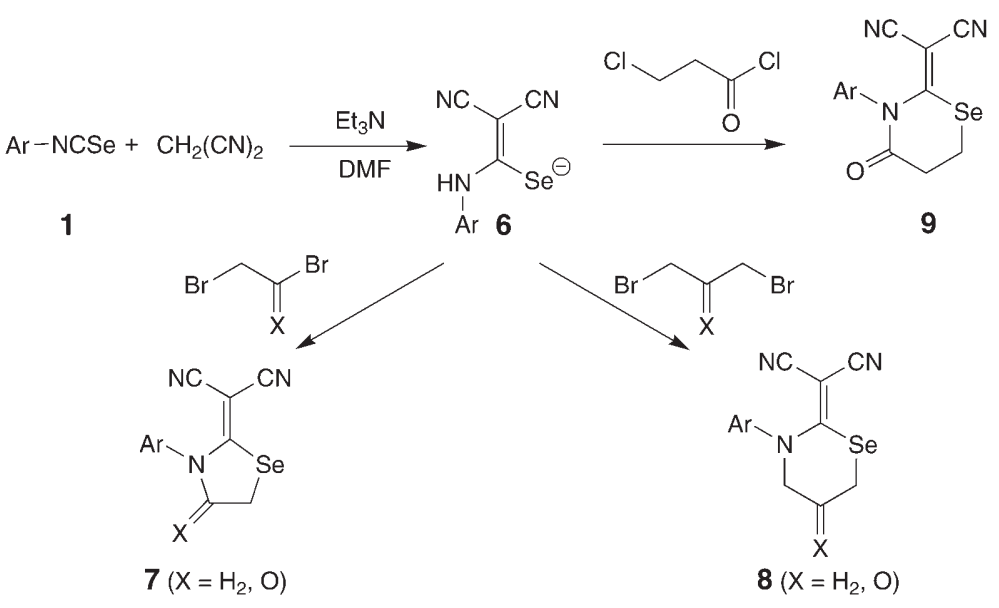

With the aim of further extending this concept, we carried out reactions of $\mathbf{1 a}(\mathrm{Ar}=$ $\mathrm{Ph})$, malononitrile, and $\alpha$-halogenated ketones or bromoacetonitrile.

2. Results and Discussion. - By following the previously described procedure [8][9], the intermediate $\mathbf{6 a}$ was generated in situ by treatment of a mixture of malononitrile and phenyl isoselenocyanate (1a) in DMF with an equimolar amount of $\mathrm{Et}_{3} \mathrm{~N}$ at room temperature (Scheme 3 ). After reaction with bromoacetonitrile, a brownish solid was isolated. On the basis of the spectroscopic data, structure $\mathbf{1 0}$ was assigned to this product. Obviously, 6a underwent an $S_{\mathrm{N}} 2$ reaction with bromoacetonitrile, but no subsequent cyclization to the expected (4-amino-1,3-selenazol-2(3H)ylidene)malononitrile $\mathbf{1 1}$ occurred (Scheme 3). All attempts to obtain a cyclized product by treatment of $\mathbf{1 0}$ with different bases failed and led to the decomposition of 10.

The CI MS of $\mathbf{1 0}$ shows the base peak at $m / z$ 306, and the elemental analysis corresponds with the molecular formula $\mathrm{C}_{12} \mathrm{H}_{8} \mathrm{~N}_{4} \mathrm{Se}$, i.e., a product, which was formed by a substitution reaction of $\mathbf{6 a}$ and bromoacetonitrile. According to the IR and ${ }^{13} \mathrm{C}$ NMR spectra, the product contains three $\mathrm{CN}$ groups $\left(2212,2201\right.$, and $2194 \mathrm{~cm}^{1}$, and $\delta(\mathrm{C}) 115.1,114.9$, and 110.1, resp.). In the ${ }^{1} \mathrm{H}$ NMR spectrum, a $\mathrm{CH}_{2}$ group absorbs at $\delta(\mathrm{H}) 4.38$ as a $s$, and a broad $s$ at $\delta(\mathrm{H}) 13.85$ can be attributed to a NH group.

2) The crystal structure of $\mathbf{8}\left(\begin{array}{cllll}\mathrm{Ar} & 4 \mathrm{Cl} & \mathrm{C}_{6} \mathrm{H}_{4}, & \mathrm{X} & \mathrm{O}\end{array}\right)$ [9] was established also by $\mathrm{X}$ ray crystallography (see below, Fig. and Table). 
Scheme 3

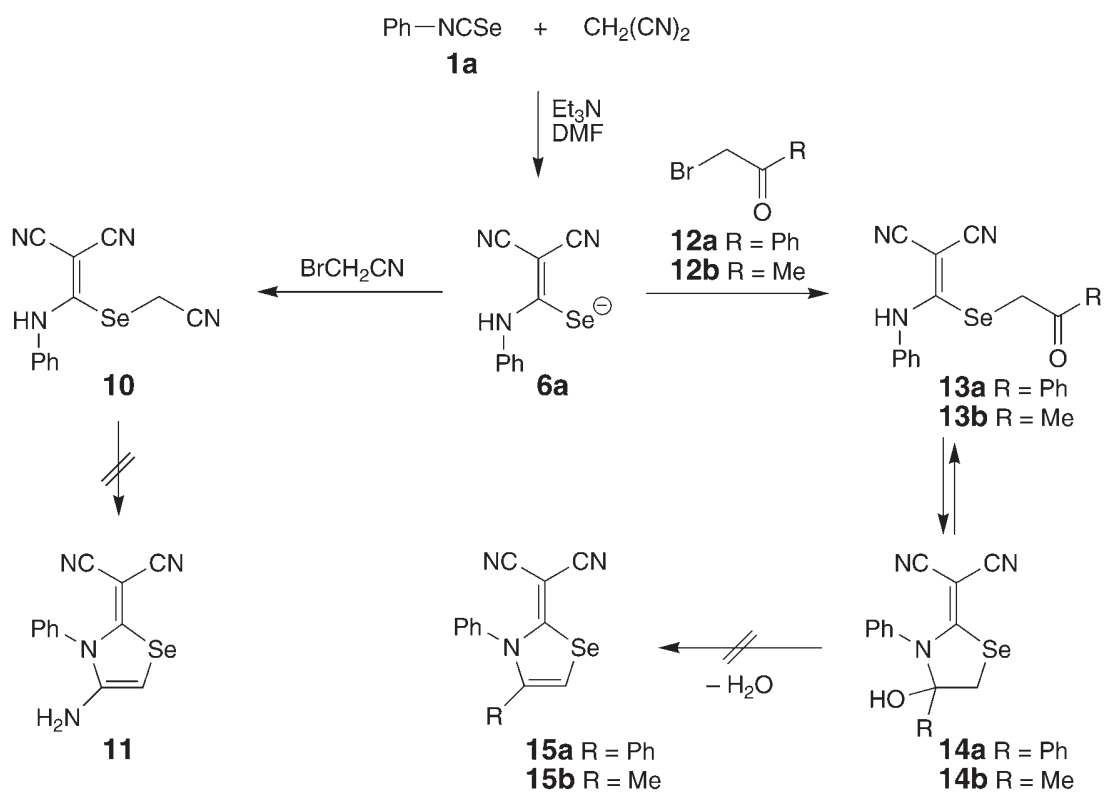

In the analogous reaction of $\mathbf{1 a}$ with malononitrile and $\alpha$-bromoacetophenone (12a) or $\alpha$-bromoacetone (12b), respectively (Scheme 3), the products were isolated as pale yellow crystals. Their data were consistent with the products of a substitution reaction of the intermediate $\mathbf{6 a}$ and the $\alpha$-halogenated ketone 12, but inconsistent with the desired products 15 (Scheme 3 ). The IR data excluded ketone derivatives 13; however, the NMR and MS data were compatible with structures $\mathbf{1 3}$ and 1,3selenazolidine derivatives 14. Taking also the X-ray analyses (see below) into account, we propose that the products which were obtained from 1a, malononitrile, and $\alpha$ halogenated ketones 12 exist in the keto form $\mathbf{1 3}$ in solution but as the cyclic 'hemiacetal' 14 in the crystalline state. Again, treatment of 13a/14a with a base did not result in the elimination of $\mathrm{H}_{2} \mathrm{O}$ to give the desired compound 15a but in the decomposition of the product.

In the IR spectrum $(\mathrm{KBr})$, the products from $\mathbf{6 a}$ and $\mathbf{1 2}$ show two signals for $\mathrm{CN}$ groups and a broad absorption at $33703400 \mathrm{~cm}{ }^{1}$, but no $\mathrm{C} O$ absorption. The ${ }^{13} \mathrm{C}$ NMR spectra indicate clearly the presence of a $\mathrm{C} O$ group $(\delta(\mathrm{C}) 196.5$ and 206.0 for the products from 12a and 12b, resp. ). Furthermore, in the ${ }^{1} \mathrm{H}$ NMR spectra, a $s$ for a $\mathrm{CH}_{2}$ group appears at $\delta(\mathrm{H}) 3.69$ and 3.64, respectively $(\delta(\mathrm{C}) 34.2$ and 36.7 in the ${ }^{13} \mathrm{C}$ NMR spectra). The CI MS and elemental analyses are in accordance with products $\mathbf{1 3}$ or 1,3 selenazolidines $\mathbf{1 4}$ but not with $\mathbf{1 5}$.

Finally, the structure of $\mathbf{1 4 a}$ was established by an X-ray crystal-structure determination (Fig.). In the crystal structure of 14a, the five-membered ring has an envelope conformation with atom $\mathrm{C}(5)$ as the envelope flap. Most of the geometric parameters are similar to those of the previously described structures of $(1,3-$ 
selenazolidin-2-ylidene)malononitriles 7 and a (1,3-selenazinan-2-ylidene)malononitrile 9 [8] [9]: the two $\mathrm{CN}$ groups are almost coplanar with the atoms $\mathrm{Se}(1), \mathrm{C}(2), \mathrm{N}(3)$, and $\mathrm{C}(6)$, the $\mathrm{C}(2)=\mathrm{C}(6)$ bond is longer $(1.389(3) \AA)$ than a normal $\mathrm{C}=\mathrm{C}$ bond, whereas the formal single bonds $\mathrm{Se}(1)-\mathrm{C}(2), \mathrm{N}(3)-\mathrm{C}(2), \mathrm{C}(6)-\mathrm{C}(7)$, and $\mathrm{C}(6)-\mathrm{C}(8)$ are short $(1.894(2), 1.332(3), 1.424(3)$, and 1.428(3) $\AA$, resp. ). Furthermore, the bond angle $\mathrm{C}(2)-\mathrm{C}(6)-\mathrm{C}(8)$ is larger than normal at $125.9(2)^{\circ}$, whereas the angles $\mathrm{C}(2)-\mathrm{C}(6)-\mathrm{C}(7)$ and $\mathrm{C}(7)-\mathrm{C}(6)-\mathrm{C}(8)$ are small $\left(117.7(2)\right.$ and $116.4(2)^{\circ}$, resp. $)$, i.e., the $\mathrm{CN}(8)$ group is tilted away from the $\mathrm{PhN}(3)$ residue. The $\mathrm{OH}$ group forms an intermolecular $\mathrm{H}$-bond with one of the cyano $\mathrm{N}$-atoms of a neighboring molecule. These interactions link the molecules into extended chains, which run parallel to the [001] direction and can be described by a graph set motif [11] of $\mathrm{C}(8)$.

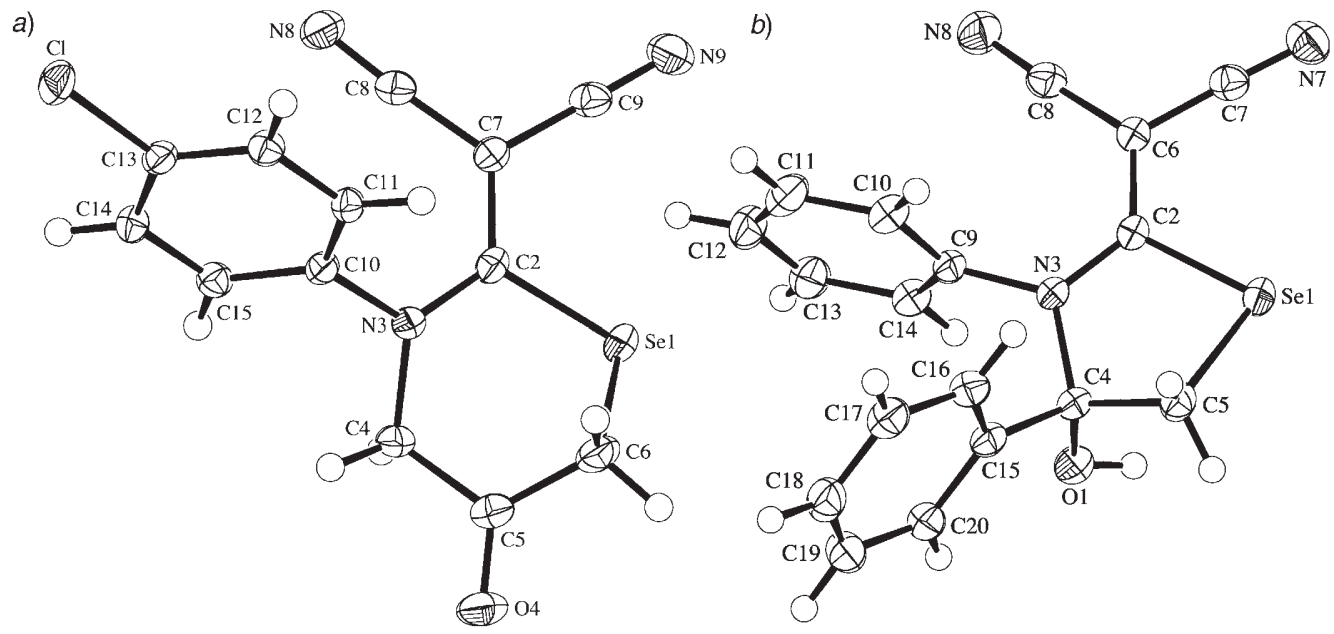

Figure. ORTEP Plots [10] of the molecular structures of a) $\mathbf{8}\left(\begin{array}{llll}\mathrm{Ar} & 4 \mathrm{Cl} & \mathrm{C}_{6} \mathrm{H}_{4}, \mathrm{X} & \mathrm{O}\end{array}\right)$ and b) $\mathbf{1 4 a}$. Arbitrary atom numbering; $50 \%$ probability ellipsoids.

The heterocycle of $\mathbf{8}\left(\mathrm{Ar}=4-\mathrm{Cl}-\mathrm{C}_{6} \mathrm{H}_{4}, \mathrm{X}=\mathrm{O}\right)$ [9] has a distorted screw-boat conformation as shown by its crystal structure (Fig.). The geometric parameters are again mostly similar to those of $\mathbf{7 , 9}$, and $\mathbf{1 4}$ (e.g., a long $\mathrm{C}(2)=\mathrm{C}(7)$ bond $(1.385(3) \AA)$ and short $\mathrm{Se}(1)-\mathrm{C}(2), \mathrm{N}(3)-\mathrm{C}(2), \mathrm{C}(7)-\mathrm{C}(8)$, and $\mathrm{C}(7)-\mathrm{C}(9)$ bonds $(1.890(2)$, $1.351(2), 1.432(3)$, and $1.427(3) \AA$, resp. ), as well as a tilting of the $\mathrm{CN}(8)$ group away from the aromatic residue (the bond angle $\mathrm{C}(2)-\mathrm{C}(7)-\mathrm{C}(8)$ is $124.9(2)^{\circ}$ and $C(8)-C(7)-C(9)$ is $\left.115.1(2)^{\circ}\right)$. In contrast, however, the environment about the $\mathrm{C}=\mathrm{C}$ bond is not planar, the plane defined by atoms $\mathrm{C}(7), \mathrm{C}(8)$, and $\mathrm{C}(9)$ making an angle of $14.3(3)^{\circ}$ with the plane defined by atoms $\mathrm{N}(3), \mathrm{C}(2)$ and $\mathrm{Se}(1)$.

In conclusion, the three-component reaction of $\mathbf{1 a}$, malononitrile, and bromoacetonitrile or $\alpha$-halogenated ketones leads to the acyclic adducts $\mathbf{1 0}$ and $\mathbf{1 3}$, respectively, in good yield via the intermediate 6a. The ketone derivatives of type $\mathbf{1 3}$ are in equilibrium with the 1,3-selenazolidine derivatives $\mathbf{1 4}$, which can be isolated in the crystalline form. 
We thank the analytical units of our institute for spectra and analyses. Financial support of this work by the Dr. Helmut Legerlotz Foundation and F. Hoffmann La Roche AG, Basel, is gratefully acknowledged.

\section{Experimental Part}

1. General. See [12][13]. TLC: silica gel $60 F_{254}$ plates $(0.25 \mathrm{~mm}$; Merck). Column chromatography (CC): silica gel 60 (0.040 $0.063 \mathrm{~mm}$; Merck). M.p.: Büchi B 540 apparatus, in capillaries; uncorrected. IR Spectra: Perkin Elmer 1600 FT IR spectrophotometer; in $\mathrm{KBr} ; v$ in $\mathrm{cm}{ }^{1} .{ }^{1} \mathrm{H}(300 \mathrm{MHz})$ and ${ }^{13} \mathrm{C}$ NMR (75.5 MHz) Spectra: Bruker $A R X 300$ instrument; in $\mathrm{CDCl}_{3}$; chemical shifts $\delta$ in ppm, $J$ in $\mathrm{Hz}$. CI MS: Finnigan SSQ 700 or MAT 90 instrument; $\mathrm{NH}_{3}$ as carrier gas; in $m / z$.

2. Starting Materials. Propanedinitrile ( malononitrile) and all halogenated compounds are commercially available (Fluka). Phenyl isoselenocyanate (1a) was prepared according to Barton's procedure starting from formanilide [14], which is commercially available (Fluka, Aldrich).

3. Reaction of 1a, Malononitrile, and a Halogenated Compound: General Procedure. To a soln. of malononitrile $(73 \mathrm{mg}, 1.1 \mathrm{mmol})$ in DMF $(10 \mathrm{ml}), \mathrm{Et}_{3} \mathrm{~N}(0.15 \mathrm{ml}, 1.1 \mathrm{mmol})$ was added, and the mixture was stirred for $30 \mathrm{~min}$ at r.t. Then, $\mathbf{1 a}(200 \mathrm{mg}, 1.1 \mathrm{mmol})$ was added, and the mixture was stirred for $1 \mathrm{~h}$ at r.t. The halogenated compound $(1.1 \mathrm{mmol})$ was added dropwise, the mixture stirred for $4 \mathrm{~h}$, and the solvent evaporated. The crude product was purified by CC (hexane/AcOEt mixtures).

2 \{[(Cyanomethyl)seleno](phenylamino)methylene\}propanedinitrile (10). From 1a, malononitrile, and bromoacetonitrile: $234 \mathrm{mg}$ (74\%) of 10. Brownish crystals. M.p. $166168^{\circ}$ (AcOEt/hexane). IR (KBr): 2212s, 2201s, 2194s, 1596w, 1554w, 1523s, 1488w, 1454m, 1415w, 1388w, 1354m, 1212w, 1200w, $1166 w, 1105 w, 1054 w, 1022 w, 1008 w, 912 w, 905 w, 888 w, 754 w, 736 w, 705 w, 698 m .{ }^{1} \mathrm{H}$ NMR: $4.38\left(s, \mathrm{CH}_{2}\right)$; 7.407 .45 (m, 2 arom. H); 7.507 .57 (m, 3 arom. H); 13.85 (br. $s, \mathrm{NH}) .{ }^{13} \mathrm{C}$ NMR: $29.1\left(\mathrm{CH}_{2}\right) ; 57.8$ $\left(C(\mathrm{CN})_{2}\right) ; 110.1,114.9,115.1(3 \mathrm{CN}) ; 128.9(2$ arom. $\mathrm{CH}) ; 129.4(2$ arom. $\mathrm{CH}) ; 130.8(1$ arom. $\mathrm{CH}) ; 134.8$ $\left(1\right.$ arom. C) $; 173.3(\mathrm{CNSe})$. CI MS: $306\left(100,\left[M\left({ }^{80} \mathrm{Se}\right)+\mathrm{NH}_{4}\right]^{+}\right), 289\left(10,\left[M\left({ }^{80} \mathrm{Se}\right)+1\right]^{+}\right)$. Anal. calc. for $\mathrm{C}_{12} \mathrm{H}_{8} \mathrm{~N}_{4} \mathrm{Se}$ (287.18): C 50.19, H 2.81, N 19.51; found: C 49.95, H 3.02, N 19.63.

$2\{[(2$ Oxo 2 phenylethyl)seleno](phenylamino)methylene\}propanedinitrile (13a)/2 (4 Hydroxy 3,4 diphenyl 1,3 selenazolidin 2 ylidene)propanedinitrile (14a). From 1a, malononitrile, and $\alpha$ bromo acetophenone (12a): $326 \mathrm{mg}$ (81\%) of 14a. Yellowish crystals. M.p. $155157^{\circ}$ (AcOEt/hexane). IR (14a; $\mathrm{KBr}): 3397 s, 3055 w, 2211 s, 2196 s, 1598 w, 1554 w, 1518 s, 1490 m, 1450 m, 1421 w, 1392 w, 1346 m, 1212 m$, $1198 w, 1168 w, 1105 w, 1075 w, 1031 w, 1015 m, 1003 w, 984 w, 931 w, 907 w, 852 w, 764 w, 737 w, 707 w, 694 m$. ${ }^{1} \mathrm{H}$ NMR (13a): $3.69\left(s, \mathrm{CH}_{2}\right) ; 6.76(d, J \quad 7.9,1$ arom. $\mathrm{H}) ; 7.03(d, J \quad 8.1,1$ arom. $\mathrm{H}) ; 7.127 .25(\mathrm{~m}, 6$ arom. H); $7.44(t, J \quad 8.1,2$ arom. H); 10.68 (br. $s, \mathrm{NH}) .{ }^{13} \mathrm{C}$ NMR $(\mathbf{1 3 a}): 34.2\left(\mathrm{CH}_{2}\right) ; 49.8\left(C(\mathrm{CN})_{2}\right)$; 111.9, $118.2(2 \mathrm{CN}) ; 126.0(1$ arom. $\mathrm{CH}) ; 126.5(2$ arom. $\mathrm{CH}) ; 127.8(2$ arom. $\mathrm{CH}) ; 128.3(2$ arom. $\mathrm{CH})$; 128.5 (2 arom. $\mathrm{CH}) ; 129.3$ (1 arom. CH); 137.1, 139.6 (2 arom. C); 172.6 (CNSe); 196.5 (CO). CI MS (14a): $385\left(100,\left[M\left({ }^{80} \mathrm{Se}\right)+\mathrm{NH}_{4}\right]^{+}\right), 368\left(10,\left[M\left({ }^{80} \mathrm{Se}\right)+1\right]^{+}\right)$. Anal. calc. for $\mathrm{C}_{18} \mathrm{H}_{13} \mathrm{~N}_{3} \mathrm{OSe}(366.28): \mathrm{C}$ 59.02, H 3.58, N 11.47; found: C 58.91, H 3.58, N 11.47.

$2\{[(2$ Oxopropyl)seleno](phenylamino)methylene\}propanedinitrile (13b)/2 (4 Hydroxy 4 methyl 3 phenyl 1,3 selenazolidin 2 ylidene)propanedinitrile (14b). From 1a, malononitrile, and $\alpha$ bromoace tone (12b): $221 \mathrm{mg}$ (66\%) of 14b. Pale yellow crystals. M.p. 170 172 (AcOEt/hexane). IR (14b; KBr): $3371 s, 2212 s, 2197 s, 1595 w, 1507 s, 1454 w, 1428 w, 1392 w, 1348 m, 1225 w, 1181 w, 1161 w, 1105 w, 1054 m, 999 w$, 953w, 903w, 851w, 744w, 694m. ${ }^{1} \mathrm{H}$ NMR (13b): $1.31(s, \mathrm{Me}) ; 3.64\left(s, \mathrm{CH}_{2}\right) ; 7.267 .31(\mathrm{~m}, 2$ arom. $\mathrm{H})$; 7.397 .49 (m, 3 arom. H); 11.45 (br. $s, \mathrm{NH}) .{ }^{13} \mathrm{C}$ NMR (13b): $25.8(\mathrm{Me}) ; 36.7\left(\mathrm{CH}_{2}\right) ; 47.7\left(\mathrm{C}(\mathrm{CN})_{2}\right)$; 112.0, 118.2 (2 CN); 129.0 (2 arom. CH); 129.7 (2 arom. CH); 130.0 (1 arom. CH); 136.5 (1 arom. C); 171.7 (CNSe); $206.2(\mathrm{CO})$. CI MS (14b): $323\left(100,\left[M\left({ }^{80} \mathrm{Se}\right)+\mathrm{NH}_{4}\right]^{+}\right), 305\left(31,\left[M\left({ }^{80} \mathrm{Se}\right)+1\right]^{+}\right)$. Anal. calc. for $\mathrm{C}_{13} \mathrm{H}_{11} \mathrm{~N}_{3} \mathrm{OSe}$ (304.21): C 51.33, H 3.64, N 13.81; found: C 51.28, H 3.71, N 13.68.

4. $X$ Ray Crystal Structure Determination of $8\left(\begin{array}{llll}\mathrm{Ar} & 4 \mathrm{Cl} \mathrm{C}_{6} \mathrm{H}_{4}, \mathrm{X} & \mathrm{O}\end{array}\right)$ and $\mathbf{1 4 a}$ (see Table and Fig. $)^{3}$ ). All measurements were made on a Nonius KappaCCD diffractometer [15] by using graphite

3) CCDC 647556 and 647557 contain the supplementary crystallographic data for this paper. These data can be obtained free of charge from the Cambridge Crystallographic Data Centre via http:// www.ccdc.ac.uk/data request/cif. 
monochromated $\mathrm{Mo}_{\alpha}$ radiation $(\lambda 0.71073 \AA)$ and an Oxford Cryosystems Cryostream 700 cooler. Data reduction was performed with HKL Denzo and Scalepack [16]. The intensities were corrected for Lorentz and polarization effects, and an absorption correction based on the multi scan method [17] was applied. Equivalent reflections were merged. Data collection and refinement parameters are given in the Table, and views of the molecules are shown in the Figure. The structure of $\mathbf{8}\left(\begin{array}{llll}\mathrm{Ar} & 4 \mathrm{Cl}^{2} & \mathrm{C}_{6} \mathrm{H}_{4}, \mathrm{X} & \mathrm{O}\end{array}\right)$ was solved by direct methods with SIR92 [18], which revealed the positions of all non $\mathrm{H}$ atoms. The non $\mathrm{H}$ atoms were refined anisotropically. The structure of 14a was solved by heavy atom Patterson methods [19], which revealed the position of the Se atom. All remaining non $\mathrm{H}$ atoms were located in a Fourier expansion of the Patterson solution, which was performed by DIRDIF 94 [20]. Non H atoms were refined anisotropically. The hydroxy $\mathrm{H}$ atom of $\mathbf{1 4 a}$ was placed in the position indicated by a difference electron density map and its position was allowed to refine together with an isotropic displacement parameter. All remaining $\mathrm{H}$ atoms and all $\mathrm{H}$ atoms of $8\left(\mathrm{Ar} 4 \mathrm{Cl} \mathrm{C}_{6} \mathrm{H}_{4}, \mathrm{X} O\right.$ ) were placed in geometrically calculated positions and refined with a riding model where each $\mathrm{H}$ atom was assigned a

Table. Crystallographic Data for Compounds $8\left(\begin{array}{llll}\mathrm{Ar} & 4 \mathrm{Cl} & \mathrm{C}_{6} \mathrm{H}_{4}, \mathrm{X} & \mathrm{O}\end{array}\right)$ and $\mathbf{1 4 a}$

\begin{tabular}{|c|c|c|}
\hline & 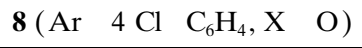 & $14 \mathbf{a}$ \\
\hline Crystallized from & $\mathrm{MeCN}$ & AcOEt/hexane \\
\hline Empirical formula & $\mathrm{C}_{13} \mathrm{H}_{8} \mathrm{ClN}_{3} \mathrm{OSe}$ & $\mathrm{C}_{18} \mathrm{H}_{13} \mathrm{~N}_{3} \mathrm{OSe}$ \\
\hline$M_{\mathrm{r}}$ & 336.58 & 366.22 \\
\hline Crystal color, habit & yellow, prism & colorless, prism \\
\hline Crystal dimensions $[\mathrm{mm}]$ & $0.07 \times 0.20 \times 0.27$ & $0.23 \times 0.23 \times 0.25$ \\
\hline Temperature $[\mathrm{K}]$ & $160(1)$ & $160(1)$ \\
\hline Crystal system & monoclinic & monoclinic \\
\hline Space group & $P 2_{1} / n$ & $C 2 / c$ \\
\hline$Z$ & 4 & 8 \\
\hline Reflections for cell determination & 18890 & 218336 \\
\hline $2 \theta$ range for cell determination $\left[{ }^{\circ}\right]$ & 460 & 460 \\
\hline Unit cell parameters: $a[\AA]$ & $9.9940(2)$ & $33.263(1)$ \\
\hline$b[\AA]$ & $12.2053(2)$ & $6.6722(2)$ \\
\hline$c[\AA]$ & $11.4240(2)$ & $14.6996(4)$ \\
\hline$\beta\left[{ }^{\circ}\right]$ & $111.419(1)$ & $109.014(2)$ \\
\hline$V\left[\AA^{3}\right]$ & $1297.25(4)$ & $3084.4(2)$ \\
\hline$D_{\mathrm{x}}\left[\mathrm{g} \mathrm{cm}^{3}\right]$ & 1.723 & 1.577 \\
\hline$\mu\left(\mathrm{MoK}_{\alpha}\right)\left[\mathrm{mm}^{1}\right]$ & 3.092 & 2.441 \\
\hline Scan type & $\phi$ and $\omega$ & $\phi$ and $\omega$ \\
\hline $2 \theta_{(\max )}\left[{ }^{\circ}\right]$ & 60 & 60 \\
\hline Transmission factors [min; max] & $0.567 ; 0.811$ & $0.498 ; 0.592$ \\
\hline Total reflections measured & 32822 & 37952 \\
\hline Symmetry independent reflections & 3786 & 4516 \\
\hline Reflections with $I>2 \sigma(I)$ & 3104 & 3627 \\
\hline Reflections used in refinement & 3786 & 4516 \\
\hline Parameters refined & 173 & 213 \\
\hline Final $\quad R(F)(I>2 \sigma(I)$ reflections $)$ & 0.0310 & 0.0410 \\
\hline$w R\left(F^{2}\right)$ (all data) & 0.0754 & 0.0993 \\
\hline Weighting parameters $[a ; b]^{\mathrm{a}}$ ) & $0.0338 ; 0.7475$ & $0.0479 ; 2.9032$ \\
\hline Goodness of fit & 1.046 & 1.102 \\
\hline Secondary extinction coefficient & $0.0024(6)$ & $0.0052(3)$ \\
\hline Final $\Delta_{\max } / \sigma$ & 0.001 & 0.004 \\
\hline$\Delta \rho(\max ; \min )\left[\mathrm{e}^{\AA}{ }^{3}\right]$ & $0.59 ; \quad 0.68$ & $0.61 ; \quad 0.75$ \\
\hline
\end{tabular}


fixed isotropic displacement parameter with a value equal to $1.2 U_{\mathrm{eq}}$ of its parent $\mathrm{C}$ atom. The refinement of each structure was carried out on $F^{2}$ by using full matrix least squares procedures, which minimized the function $\Sigma w\left(F_{\mathrm{o}}^{2} \quad F_{\mathrm{c}}^{2}\right)^{2}$. Corrections for secondary extinction were applied. Neutral atom scattering factors for non $\mathrm{H}$ atoms were taken from [21a], and the scattering factors for $\mathrm{H}$ atoms were taken from [22]. Anomalous dispersion effects were included in $F_{\mathrm{c}}$ [23]; the values for $f^{\prime}$ and $f^{\prime \prime}$ were those of [21b]. The values of the mass attenuation coefficients are those of [21c]. All calculations were performed with the SHELXL97 [24] program.

\section{REFERENCES}

[1] Y. Zhou, A. Linden, H. Heimgartner, Helv. Chim. Acta 2000, 83, 1576.

[2] P. K. Atanassov, A. Linden, H. Heimgartner, Helv. Chim. Acta 2004, 87, 1452.

[3] G. L. Sommen, A. Linden, H. Heimgartner, Eur. J. Org. Chem. 2005, 14, 3128.

[4] M. Koketsu, T. Sakai, T. Kiyokuni, D. R. Garud, H. Ando, H. Ishikara, Heterocycles 2006, 68, 1607; D. R. Garud, M. Koketsu, H. Ishihara, Molecules 2007, 12, 504.

[5] P. K. Atanassov, A. Linden, H. Heimgartner, Helv. Chim. Acta 2004, 87, 1873.

[6] G. L. Sommen, A. Linden, H. Heimgartner, Heterocycles 2005, 65, 1903; F. Favero, G. L. Sommen, A. Linden, H. Heimgartner, Heterocycles 2006, 67, 749.

[7] J. E. Baldwin, J. Chem. Soc., Chem. Commun. 1976, 734.

[8] G. L. Sommen, A. Linden, H. Heimgartner, Tetrahedron 2006, 62, 3344.

[9] G. L. Sommen, A. Linden, H. Heimgartner, Helv. Chim. Acta 2007, 90, 472.

[10] C. K. Johnson, 'ORTEP II', Report ORNL 5138, Oak Ridge Natioal Laboratory, Oak Ridge, Tennessee, 1976

[11] J. Bernstein, R. E. Davis, L. Shimoni, N. L. Chang, Angew. Chem., Int. Ed. Engl. 1995, 34, 1555.

[12] P. K. Atanassov, Y. Zhou, A. Linden, H. Heimgartner, Helv. Chim. Acta 2002, 85, 1102.

[13] Y. Zhou, H. Heimgartner, Helv. Chim. Acta 2000, 83, 539.

[14] D. H. R. Barton, S. I. Parekh, M. Tajbakhsh, E. A. Theodorakis, C. L. Tse, Tetrahedron 1994, 50, 639; M. T. Bakhsh, Y. S. Behshtiha, M. M. Heravi, J. Chem. Soc. Pakistan, 1996, 18, 159.

[15] R. Hooft, KappaCCD Collect Software, Nonius BV, Delft, The Netherlands, 1999.

[16] Z. Otwinowski, W. Minor, in 'Methods in Enzymology', Vol. 276, 'Macromolecular Crystallography', Part A, Eds. C. W. Carter Jr. and R. M. Sweet, Academic Press, New York, 1997, p. 307.

[17] R. H. Blessing, Acta Crystallogr., Sect. A 1995, 51, 33.

[18] A. Altomare, G. Cascarano, C. Giacovazzo, A. Guagliardi, M. C. Burla, G. Polidori, M. Camalli, SIR92, J. Appl Crystallogr. 1994, 27, 435.

[19] P. T. Beurskens, G. Admiraal, G. Beurskens, W. P. Bosman, S. Garcia Granda, R. O. Gould, J. M. M. Smits, C. Smykalla, PATTY: The DIRDIF Program System, Technical Report of the Crystallog raphy Laboratory, University Nijmegen, The Netherlands, 1992.

[20] P. T. Beurskens, G. Admiraal, G. Beurskens, W. P. Bosman, R. de Gelder, R. Israel, J. M. M. Smits, DIRDIF 94: The DIRDIF Program System, Technical Report of the Crystallography Laboratory, University Nijmegen, The Netherlands, 1994.

[21] a) E. N. Maslen, A. G. Fox, M. A. O'Keefe, in 'International Tables for Crystallography', Ed. A. J. C. Wilson, Kluwer Academic Publishers, Dordrecht, 1992, Vol. C, Table 6.1.1.1, p. 477; b) D. C. Creagh, W. J. McAuley, in 'International Tables for Crystallography', Ed. A. J. C. Wilson, Kluwer Academic Publishers, Dordrecht, 1992, Vol. C, Table 4.2.6.8, p. 219; c) D. C. Creagh, J. H. Hubbell, in 'International Tables for Crystallography', Ed. A. J. C. Wilson, Kluwer Academic Publishers, Dordrecht, 1992, Vol. C, Table 4.2.4.3, p. 200.

[22] R. F. Stewart, E. R. Davidson, W. T. Simpson, J. Chem. Phys. 1965, 42, 3175.

[23] J. A. Ibers, W. C. Hamilton, Acta Crystallogr. 1964, 17, 781.

[24] G. M. Sheldrick, SHELXL97, Program for the Refinement of Crystal Structures, University of Göttingen, Germany, 1997. 